\title{
Performance of Bamboo based Agri-silvicultural Systems in North Odisha, India
}

\author{
Suryakanta Behera ${ }^{1 *}$, A. K. Mahapatra ${ }^{2}$, P. J. Mishra ${ }^{3}$, S. Pattanayak ${ }^{4}$ and D. Panda ${ }^{5}$
}

${ }^{1}$ Dept. of Silviculture \& Agroforestry, College of Forestry, ${ }^{2 \& 4}$ Dept. of Agronomy, College of Agriculture, ${ }^{3}$ AICRP on Agroforestry, College of Forestry, Orissa University of Agriculture \& Technology, Bhubaneswar, Odisha (751 003), India

${ }^{5}$ Institute of Agriculture, Visva-Bharati University, Sriniketa, West Bengal (731 236), India

\section{Article History}

Manuscript No. AR1542

Received in $22^{\text {nd }}$ February, 2016

Received in revised form $19^{\text {th }}$ March, 2016

Accepted in final form $2^{\text {nd }}$ April, 2016

\section{Correspondence to}

*E-mail: suryakantarrr@gmail.com

\section{Keywords}

Agri-silvi systems, bamboo, intercrops, yield, economics

\begin{abstract}
A field experiment was conducted at Gobardhansul village of Baripada block, Mayurbhanj, during Kharif season of June, 2014 to study the performance of bamboo based agri-silvicultural systems in north Odisha. The silvicultural component Bambusa Vulgaris was grown at three different spacings $\left(5 \times 5 \mathrm{~m}^{2}, 8 \times 5 \mathrm{~m}^{2}\right.$ and $\left.8 \times 8 \mathrm{~m}^{2}\right)$ and four intercrops (cowpea, rice bean, turmeric and yam) were taken up within the interspaces in a randomized block design with 3 replications. Cowpea (Var: Utkalmanika), rice bean (var: SRBS-35), turmeric (var. Surama) and yam (var: Orissa Elite) were sown on $2^{\text {nd }}$ July 2014 with recommended agronomic management practices and received $963.4 \mathrm{~mm}$ rainfall during the growing season. Maximum clump height, clump girth, total numbers of culms/clump and canopy diameter were recorded in bamboo at $8 \times 8 \mathrm{~m}^{2}$ spacing followed by $8 \times 5 \mathrm{~m}^{2}$ spacing. The narrowest spacing of $5 \times 5 \mathrm{~m}^{2}$ had the lowest values of all growth parameters during the period of study. Irrespective of the spacing, cowpea and rice bean intercropped with bamboo recorded significantly more growth of bamboo as compared to turmeric and yam. All the intercrops yielded maximum at wider spacing and yield decreased progressively with decrease in spacing from $8 \times 8 \mathrm{~m}^{2}$ to $5 \times 5 \mathrm{~m}^{2}$. The decrease in bamboo yield obtained from $8 \times 8 \mathrm{~m}^{2}$ spacing was to the extent of 15.57 and $6.80 \%$, respectively over the narrower spacing of $5 \times 5 \mathrm{~m}^{2}$ and $8 \times 5 \mathrm{~m}^{2}$.
\end{abstract}

\section{Introduction}

Bamboo forest occupies $3.2 \%$ of the world's total forest area. It is estimated that worldwide there are over 1200 species under 87 genera of bamboo, with a natural distribution across a broad range of environments (humid tropical, subtropical and temperate region) on all continents except Europe and Antarctica (Ram et al., 2010; Hogarth and Belcher, 2013). According to Forest Survey of India (FSI), in India bamboo is grown in 8.96 mha of forest area $(12.8 \%$ of total forest area of the country. Of this, nearly $28 \%$ occur in the North Eastern States, followed by $20.3 \%$ in Madhya Pradesh, $9.90 \%$ in Maharashtra, 8.7\% in Orissa, 7.4\% in Andhra Pradesh, 5.5\% in Karnataka and the balance is spread over in other states. It is the second richest country in terms of bamboo genetic diversity after China with a total of 136 species in 75 genera (Biswas, 2004; Rai and Chaudhary, 1998). Trees on farmland or in forest form an integral part of the farming system. These days' forest resources are dwindling day by day in quantity, quality and diversity due to generation of more pressure for food, fodder and fuel requirements to satisfy the basic needs of increasing human and livestock population. In this context, agroforestry with emphasis on bamboo can play a vital role to meet the diversified need of the growing population for sustaining rural livelihoods. Bamboo based agroforestry models provide higher economic returns to the farmers, improve the soil health, fill the gap of national forest cover $(33 \%)$ and provide raw material to the industry as well as for domestic use of the rural community. Bambusa vulgaris is a multipurpose bamboo with culms of 10 to $16 \mathrm{~m}$ in length. The diameter of the culms is $5-10 \mathrm{~cm}$ with a wall thickness ranging from 7-15 mm. The objective of taking pulses as intercrops is to improve and maintain soil fertility besides complementing in growth and productivity of bamboo. With this background, in this present investigation anattempt is made to assess the effect of Bambusa vulgaris planted at different spacing with different intercrops in agri-silvicultural systems under North Odisha condition. 


\section{Materials and Methods}

The field experiment was carried out at Gobardhansul village of Baripada block, Mayurbhanj, Odisha during June, 2014 to February 2015. The site was located at $21^{\circ} 55^{\prime} 914^{\prime \prime}$ North longitude and $86^{\circ} 48^{\prime} 08^{\prime \prime}$ East latitude with an altitude of 36 meter above mean sea level. The normal average rainfall of the location is $1600.6 \mathrm{~mm}$ with 77 rainy days in a year which is mostly received from the south-west monsoon. The monsoon sets on around mid-June and recedes by mid-October. The rainfall received during the cropping season from June 2014 to February 2015 was $1307.8 \mathrm{~mm}$ in 82 rainy days. June was the hottest month of the year with a mean maximum temperature of $35.46{ }^{\circ} \mathrm{C}$ while December was the coolest month of the year with a mean minimum of $11.77^{\circ} \mathrm{C}$. The soil was sandy loam in texture and before beginning of the crop the amount of soil organic carbon, available nitrogen, phosphorous, potassium were $0.42 \%, 165.5 \mathrm{~kg} \mathrm{ha}^{-1}, 18.6 \mathrm{~kg} \mathrm{ha}^{-1}$ and $145.5 \mathrm{~kg} \mathrm{ha}^{-1}$ e.g. low in organic carbon, nitrogen, medium in phosphorus and potassium. The plantations of Bambusa vulgaris was established in July, 2009 at different spacing of $5 \times 5 \mathrm{~m}^{2}, 8 \times 5$ $\mathrm{m}^{2}$ and $8 \times 8 \mathrm{~m}^{2}$. The experiment was conducted in RBD with three replications and there were 12 treatment combinations. The treatment combinations comprised of three spacings of bamboo (Bambusa vulagaris) i.e. $5 \times 5 \mathrm{~m}^{2}, 8 \times 5 \mathrm{~m}^{2}$ and $8 \times 8 \mathrm{~m}^{2}$ and four intercrops i.e. cowpea, rice bean, turmeric and yam. The intercrops cowpea, ricebean, and turmeric were sown at $45 \times 25 \mathrm{~cm}^{2}$ spacing and yam at $2.5 \times 0.75 \mathrm{~m}^{2}$ spaced pitsduring the year of experimentation.

At the time of final land preparation well decomposed FYM was applied @ $10 \mathrm{t} \mathrm{ha}^{-1}$. The fertilizer dose of 25-50-50 kg $\mathrm{N}-\mathrm{P}_{2} \mathrm{O}_{5}-\mathrm{K}_{2} \mathrm{O}$ ha $^{-1}$ for cowpea, 40-40-20 kg N-P $\mathrm{O}_{5}-\mathrm{K}_{2} \mathrm{O}$ ha ${ }^{-1}$ for ricebean, 60-30-90 kg N-P $\mathrm{O}_{5}-\mathrm{K}_{2} \mathrm{O}$ ha ${ }^{-1}$ for turmeric and 80-60-60 kg N-P $\mathrm{O}_{5}-\mathrm{K}_{2} \mathrm{O}$ ha $^{-1}$ were applied. Gap filling was done 10 days after planting in case of causality.

Hoeing and weeding were carried out at three weeks interval for initial three months for every crop. Irrigation was given as per requirement of the crop at different growth stages to avoid any form of moisture stress during crop growth period. The major disease for the cowpea, rice bean, turmeric and yam was leaf spot and the major insect pest was termite. For the control of leaf spot Dithen M-45+Mancozeb W.P @ 2 g liter $^{-1}$ was applied as foliar spray. For the control of termites, Chloropyriphos@2 ml liter ${ }^{-1}$ was applied as direct spray. Harvesting was carried out as per maturity of crops. Cowpea was harvested during September-October, ricebean was harvested during October and turmeric and yam was during February.

\section{Results and Discussion}

3.1. Performance of bamboo and agricultural crops under agri-silvicultural systems
Growth of bamboo i.e. clump height, clump girth, number of culms per clump of bamboo, canopy diameter in agrisilvicultural system was recorded and presented in Table 1. The value of all above parameter (clump height, clump girth, number of culms and canopy diameter) was found maximum under bamboo $\left(8 \times 8 \mathrm{~m}^{2}\right)$ with cowpea. Maximum clump height was found in $8 \times 8 \mathrm{~m}^{2}$ spacing followed by the narrower spacing of $8 \times 5 \mathrm{~m}^{2}$ and $5 \times 5 \mathrm{~m}^{2}$ irrespective of different intercrops grown. The clump height was found more when bamboo was intercropped with cowpea followed by ricebean, turmeric and yam. The same trend was evident irrespective of different spacing in bamboo. The maximum clump height of $15.25 \mathrm{~m}$ was recorded with bamboo $\left(8 \times 8 \mathrm{~m}^{2}\right)$ and cowpea and the minimum clump height of $11 \mathrm{~m}$ was observed with bamboo planted $\left(5 \times 5 \mathrm{~m}^{2}\right)$ with yam as intercrop. Maximum clump girth of $6.51 \mathrm{~m}$ observed with bamboo planted at $8 \times 8 \mathrm{~m}^{2}$ spacing with cowpea and the clump girth decreased progressively with decrease in spacing. Minimum clump girth of $4.33 \mathrm{~m}$ was recorded with bamboo at $5 \times 5 \mathrm{~m}^{2}$ spacing intercropped with yam. The clump girth of bamboo was maximum with cowpea followed by rice bean, turmeric and minimum with yam irrespective of the different spacing's in bamboo.

Total number of culms of bamboo clump ${ }^{-1}$ (47.8) was found maximum under bamboo $\left(8 \times 8 \mathrm{~m}^{2}\right)$ with cowpea. This treatment was significantly superior to all the treatment combination and found minimum in the narrower spacing of $5 \times 5 \mathrm{~m}^{2}$ irrespective of the intercrops grown. Minimum number of culm clump ${ }^{-1}(40)$ was evident in bamboo $(5 \times 5$ $\left.\mathrm{m}^{2}\right)$ with yam. Maximum canopy diameter $(7.47 \mathrm{~m})$ was registered with the same spacing bamboo $\left(8 \times 8 \mathrm{~m}^{2}\right)$ with cowpea followed by bamboo $\left(8 \times 8 \mathrm{~m}^{2}\right)$ with ricebean among all intercrops. Bamboo put forth more canopy diameter when intercropped with cowpea over rice bean, turmeric and yam respectively. Minimum canopy diameter $(5.25 \mathrm{~m})$ was recorded under bamboo $\left(5 \times 5 \mathrm{~m}^{2}\right)$ with yam. Dev et al. 2014, working with Dendrocalamus strictus and Bambusa vulgaris and intercrops have reported that height, number of culms and canopy diameter of bamboo have increased substantially when bamboo is grown in association with black gram and chick pea. Similarly, Kumar et al. (2014) reported higher growth parameters of bamboo when grown in association with ricebean under foot hills of Nagaland. In the All India Coordinated Research Project under Agroforestry at Bhubaneswar and Jhargram, West Bengal, growth of bamboo was more (more height, leaves, biomass and crown diameter) with intercrops than without intercrops.

This suggests that intercrops like pulses have a more positive effect on growth of silvi species over other intercrops due to addition and easy decomposition of leaf litter resulting in increased organic matter content of the soil. Similar findings have been reported by several workers working in 


\begin{tabular}{|c|c|c|c|c|c|c|c|c|c|}
\hline Treatment & $\begin{array}{l}\text { Clump } \\
\text { height } \\
(\mathrm{m})\end{array}$ & $\begin{array}{l}\text { Clump } \\
\text { girth } \\
(\mathrm{m})\end{array}$ & $\begin{array}{l}\text { Total } \\
\text { culms } \\
\text { clum }^{-1} \\
\text { ps }\end{array}$ & $\begin{array}{l}\text { Canopy } \\
\text { diameter } \\
(\mathrm{m})\end{array}$ & $\begin{array}{c}\text { Bamboo } \\
\text { biomass } \\
\text { Yield } \\
\left(\mathrm{t} \mathrm{ha}^{-1}\right)\end{array}$ & $\begin{array}{l}\text { Crop } \\
\text { yield } \\
(\mathrm{q} \\
\left.\mathrm{ha}^{-1}\right)\end{array}$ & $\begin{array}{l}\text { Gross } \\
\text { return } \\
\left(₹ h^{-1}\right)\end{array}$ & $\begin{array}{c}\text { Net } \\
\text { return } \\
\left(₹ h^{-1}\right)\end{array}$ & $\begin{array}{l}\text { Benefit: } \\
\text { cost } \\
\text { ratio }\end{array}$ \\
\hline $\mathrm{T}_{1}$-Bamboo $\left(5 \times 5 \mathrm{~m}^{2}\right)+$ Cowpea & 12.52 & 4.85 & 42.7 & 5.90 & 38.4 & 28.56 & $1,19,640$ & 54,640 & 1.84 \\
\hline $\mathrm{T}_{2}-$ Bamboo $\left(5 \times 5 \mathrm{~m}^{2}\right)+$ Rice bean & 12.22 & 4.70 & 40.8 & 5.79 & 36.8 & 4.92 & 79,504 & 24,504 & 1.44 \\
\hline $\mathrm{T}_{3}$-Bamboo $\left(5 \times 5 \mathrm{~m}^{2}\right)+$ Turmeric & 11.77 & 4.45 & 40.2 & 5.43 & 34.6 & 42.12 & $1,32,380$ & 32,380 & 1.32 \\
\hline $\mathrm{T}_{4}$-Bamboo $\left(5 \times 5 \mathrm{~m}^{2}\right)+$ Yam & 11.00 & 4.33 & 40.0 & 5.25 & 34.4 & 61.92 & $1,61,680$ & 81,680 & 2.02 \\
\hline $\mathrm{T}_{5}$-Bamboo $\left(8 \times 5 \mathrm{~m}^{2}\right)+$ Cowpea & 13.12 & 5.47 & 46.3 & 6.87 & 42.3 & 32.88 & $1,33,920$ & 73,920 & 2.23 \\
\hline $\mathrm{T}_{6}-$ Bamboo $\left(8 \times 5 \mathrm{~m}^{2}\right)+$ Rice bean & 12.94 & 5.20 & 44.5 & 6.66 & 41.3 & 5.75 & 89,500 & 39,500 & 1.79 \\
\hline $\mathrm{T}_{7}$-Bamboo $\left(8 \times 5 \mathrm{~m}^{2}\right)+$ Turmeric & 12.31 & 5.11 & 42.2 & 6.11 & 40.3 & 46.57 & $1,50,455$ & 55,455 & 1.58 \\
\hline $\mathrm{T}_{8}$-Bamboo $\left(8 \times 5 \mathrm{~m}^{2}\right)+$ Yam & 12.20 & 5.23 & 42.0 & 5.95 & 40.5 & 66.55 & $1,80,825$ & $1,05,825$ & 2.41 \\
\hline $\mathrm{T}_{9}$-Bamboo $\left(8 \times 8 \mathrm{~m}^{2}\right)+$ Cowpea & 15.25 & 6.51 & 47.8 & 7.47 & 46.5 & 35.57 & $1,46,355$ & 91,355 & 2.66 \\
\hline $\mathrm{T}_{10}-$ Bamboo $\left(8 \times 8 \mathrm{~m}^{2}\right)+$ Rice bean & 14.27 & 6.20 & 45.2 & 7.12 & 44.5 & 6.88 & 97,256 & 52,256 & 2.16 \\
\hline $\mathrm{T}_{11}$-Bamboo $\left(8 \times 8 \mathrm{~m}^{2}\right)+$ Turmeric & 13.46 & 5.68 & 42.2 & 6.90 & 42.5 & 49.30 & $1,58,950$ & 68,950 & 1.76 \\
\hline $\mathrm{T}_{12}-$ Bamboo $\left(8 \times 8 \mathrm{~m}^{2}\right)+$ Yam & 13.11 & 5.55 & 41.6 & 5.88 & 46.3 & 71.11 & $1,99,265$ & $1,29,265$ & 2.84 \\
\hline $\mathrm{SEm} \pm$ & 0.012 & 0.010 & 0.151 & 0.155 & 0.45 & 1.16 & - & & \\
\hline $\mathrm{CD}(p=0.05)$ & 0.034 & 0.029 & 0.452 & 0.464 & 1.32 & 3.45 & - & & \\
\hline
\end{tabular}

agroforestry system viz. Shanmughavel and Francis (2001); Singh and Singh (1999); Banerjee et al. (2009) who have opined that association of intercrops especially pulses are able to fix atmospheric nitrogen upon their decomposition thereby increase soil physical condition and help in uptake of more nutrients as compared to bamboo grown in open condition e.g. without intercrops.

\subsection{Yield of intercrops}

The yield of intercrops i.e. cowpea, ricebean, turmeric and yam at different spacing of bamboo was presented in Table 2 . There were significant variations in yield of intercrops at different spacing of bamboo. The yield of all the intercrops increased progressively with increase in spacing of $5 \times 5 \mathrm{~m}^{2}$ to $8 \times 8 \mathrm{~m}^{2}$. The narrower spacing of $5 \times 5 \mathrm{~m}^{2}$ recorded $18.6 \%$ less yield of intercrops than the wider spacing of $8 \times 8 \mathrm{~m}^{2}$. No significant difference in intercrop yield was evident between $5 \times 5 \mathrm{~m}^{2}$ and $8 \times 8 \mathrm{~m}^{2}$ spacing but in wider spacing of $8 \times 8 \mathrm{~m}^{2}$, the yield difference was significant. Among the intercrops, yam recorded the maximum rhizome yield followed by turmeric. Maximum intercrop yield of $71.11 \mathrm{q} \mathrm{ha}^{-1}$ was observed with yam at $8 \times 8 \mathrm{~m}^{2}$ spacing followed by $8 \times 5 \mathrm{~m}^{2}$ spacing and $5 \times 5$ $\mathrm{m}^{2}$ spacing. Minimum yield was recorded with ricebean at all the spacing's. Yield performance of intercrops followed the order of yam $>$ turmeric $>$ cowpea $>$ rice bean. Singh and Singh, 1999 and Banerjee et al. 2009 also reported similar findings in bamboo grown with different intercrops under different spacing. The yield of intercrops varied with variation in spacing and increased yield from wider spacing was evident.

\subsection{Economics of different agri-silvicultural systems}

This experiment revealed that the economic parameters such as biomass yield, gross return, net return and $\mathrm{B}: \mathrm{C}$ ratio of different intercrops varied significantly among the different treatments Table 1 . The biomass yield of bamboo under agrisilvisystem ranged from $34.4 \mathrm{tha}^{-1}$ under bamboo $\left(5 \times 5 \mathrm{~m}^{2}\right)$ with yam to $46.5 \mathrm{t} \mathrm{ha}^{-1}$ under bamboo $\left(8 \times 8 \mathrm{~m}^{2}\right)$ with cowpea. The next best bamboo biomass yield was observed with bamboo $\left(8 \times 8 \mathrm{~m}^{2}\right)$ with yam $\left(46.3 \mathrm{~kg} \mathrm{ha}^{-1}\right)$ and bamboo $(8 \times 8$ $\left.\mathrm{m}^{2}\right)$ with rice bean $\left(44.5 \mathrm{~kg} \mathrm{ha}^{-1}\right)$ and bamboo $\left(5 \times 5 \mathrm{~m}^{2}\right)$ with

Table 2: Yield of intercrops ( $\mathrm{q} \mathrm{ha}^{-1}$ ) as influenced by different spacing's and intercrops of bamboo in agrisilvicultural systems

\begin{tabular}{|c|c|c|c|c|c|}
\hline \multirow{3}{*}{$\begin{array}{l}\text { Treatments } \\
\text { Spacing }\end{array}$} & \multicolumn{5}{|c|}{ Crop } \\
\hline & $\begin{array}{c}\mathrm{C}_{1} \\
\left(\mathrm{q} \mathrm{ha}^{-1}\right) \\
(\text { cow } \\
\text { pea) }\end{array}$ & $\begin{array}{c}\mathrm{C}_{2} \\
\left(\mathrm{q} \mathrm{ha}^{-1}\right) \\
(\text { Rice } \\
\text { bean })\end{array}$ & $\begin{array}{c}\mathrm{C}_{3} \\
\left(\mathrm{q} \mathrm{ha}^{-1}\right) \\
(\text { Tur } \\
\text { meric) }\end{array}$ & $\begin{array}{c}\mathrm{C}_{4} \\
\left(\mathrm{q} \mathrm{ha}^{-1}\right) \\
(\text { Yam })\end{array}$ & Mean \\
\hline & & & & & \\
\hline $\mathrm{S}_{1}\left(5 \times 5 \mathrm{~m}^{2}\right)$ & 28.56 & 4.92 & 42.12 & 61.92 & 34.38 \\
\hline $\mathrm{S}_{2}\left(8 \times 5 \mathrm{~m}^{2}\right)$ & 32.88 & 5.75 & 46.57 & 66.55 & 37.94 \\
\hline $\mathrm{S}_{3}\left(8 \times 8 \mathrm{~m}^{2}\right)$ & 35.57 & 6.88 & 49.30 & 71.11 & 40.72 \\
\hline Mean & 32.34 & 5.85 & 46.00 & 66.53 & \\
\hline $\mathrm{SEm} \pm$ & \multicolumn{5}{|c|}{1.16} \\
\hline $\mathrm{CD}(p=0.05)$ & \multicolumn{5}{|c|}{3.45} \\
\hline
\end{tabular}


yam recorded lowest yield of $34.4 \mathrm{tha}^{-1}$ which was at par with bamboo with turmeric ( $\left.34.6 \mathrm{~kg} \mathrm{ha}^{-1}\right)$ and bamboo with rice bean at same $5 \times 5 \mathrm{~m}^{2}$ spacing $\left(36.8 \mathrm{~kg} \mathrm{ha}^{-1}\right)$. Maximum gross return (₹ $1,99,265 /-)$ was obtained from yam grown under bamboo $\left(8 \times 8 \mathrm{~m}^{2}\right)$ spacing followed by bamboo $\left(8 \times 5 \mathrm{~m}^{2}\right)$ with yam (₹ $1,80,825 \mathrm{ha}^{-1}$ however, rice bean under bamboo $\left(5 \times 5 \mathrm{~m}^{2}\right)$ resulted minimum gross return of $₹ 79,504 \mathrm{ha}^{-1}$.

The net return from intercrops ranged from ₹ $24504 \mathrm{ha}^{-1}$ to ₹ $129265 \mathrm{ha}^{-1}$. Yam under bamboo excelled over others. Yam under bamboo recorded significantly higher return over turmeric, cowpea and rice bean. Yam and turmeric performed better under agri-silvicultural system than cowpea and rice bean. The B:C ratio of intercrops ranged from 1.32 to 2.84 . Bamboo $\left(8 \times 8 \mathrm{~m}^{2}\right)$ with yam exhibited the highest $\mathrm{B}: \mathrm{C}$ ratio $(2.84)$ and was at par with bamboo $\left(8 \times 8 \mathrm{~m}^{2}\right)$ with cowpea (2.66) and bamboo $\left(8 \times 5 \mathrm{~m}^{2}\right)$ with yam (2.41). Bamboo $\left(5 \times 5 \mathrm{~m}^{2}\right)$ with turmeric exhibited lowest B:C ratio (1.32) and was significantly at par with bamboo with rice bean of same spacing (1.44). Osman et al. (2011) reported similar findings and reported higher gross and net return and benefit: cost ratio were primarily due to differences in LER and cost of cultivation in different treatments. Pandea et al. (2012), Rahangdale et al. (2014); Karthik and Amarnath (2014) had similar observations in bamboo based agri-silvicultural systems.

\section{Conclusion}

Bambusa vulgaris planted at $8 \times 8 \mathrm{~m}^{2}$ spacing with yam as intercrop produced the maximum bamboo biomass yield of $46.3 \mathrm{t} \mathrm{ha}^{-1}$ and intercrop yield of $71.11 \mathrm{q} \mathrm{ha}^{-1}$ at $5^{\text {th }}$ year of bamboo plantation. The highest gross return (₹ 1,99,265 $\mathrm{ha}^{-1}$ ), net return (₹ $1,29,265 \mathrm{ha}^{-1}$ ) and benefit: cost ratio (2.84) was also obtained from same treatment in North Odisha condition. Therefore farmers should practice bamboo based agroforestry systems rather than bamboo plantation alone to maximize the profit.

\section{References}

Ahlawat, S.P., 2014. Bamboo based agroforestry for livelihood security and environmental protection in the semi-arid region of India. Annual report of world congress on agroforestry, 1069.

Aseri, G.K., Sinha, B.K.P., Agarwal, D., Sharma, A., Jain, N., Babu, V., 2012. New and improved method of bamboo cultivation in semi-arid areas of Indian Thar Desert.African Journal of Biotechnology 11(84), 15002-15011.

Babu, N., Shukla, A.K., Tripathi, P.C., Prusty, M., 2015. Traditional Cultivation Practices of Turmeric in Tribal Belt of Odisha. Journal of Engineering Computers \& Applied Sciences (JECAS) 4(2), 52-57.
Banerjee, H., Dhara, P.K., Mazumdar, D., 2009. Bamboo (Bambusa spp.) based agroforestry systems under rainfed upland ecosystem, India. Journal of Crop and Weed 5(1), 286-290.

Chauhan, S.K, Dhillon, W.S., Singh, N., Sharma, R., 2013. Physiological Behaviour and Yield Evaluation of Agronomic Crops Under Agri-horti-silviculture System. International Journal of Plant Research 3(1), 1-8.

Dev, I., Dhyani, S.K., Sridhar, K.B., Ahlawat, S.B., Newaj, R., Tewari, R.K., Kumar, R.V., Singh, R., Yadav, R.S., Venkatesh, A., Dwivedi, R.P., Palsaniya, D.R., 2014. Assessment of growing stock of bamboo under agroforestry systems in central India. Annual report of world congress on agroforestry, 009.

Giller, E.K., Rowe, E.C., Ridder, N.D., Keulen, H.V., 2006. Resource use dynamics and interactions in the tropics: Scaling up in space and time. Agricultural Systems 88, $8-27$.

Kiran, M., Bibi, R., Jillani, M.S., Waseem, K., Ullah, G., Javeria, S., and Niamatullah, M., 2013. Effect of plant spacing on profitable yield of turmeric (curcuma longa L.). Pakistan Journal of Science 65(4), 486-491.

Osman, A.N., Raebild, A., Christiansen, J.L., Bayala, J., 2011. Performance of cowpea (Vigna unguiculata) and pearl millet (Pennisetum glaucum) intercropped under Parkia biglobosain an agroforestry system in Burkina Faso. African Journal of Agricultural Research 6(4),882-891.

Pandea, V.C., Kurothea, R.S., Raoa, B.K., Kumar,G., Parandiyal, A.K., Singh, A.K., Kumar, A., 2012. Economic Analysis of Bamboo Plantation in Three Major Ravine Systems of India.Agricultural Economics Research Review 25(1), 49-59.

Rahangdale, C.P., Pathak, N.N., Kosht, L.D., 2014. Impact of bamboo species on growth and yield attributes of Kharif crops under agroforestry system in wasteland condition of the Central India. International journal of agroforestry and silviculture 1(3), 031-036.

Scurlock, J.M.O., Dayton, D.C., Hames, B., 2000. Bamboo: an overlooked biomass resource? Biomass and Bioenergy 19, 229-244.

Shanmughavel, P., Francis, K. (1999). Growth performance and economic returns of pigeon pea in agroforestry. Indian Journal of Forestry 22(4), 351-353.

Silva, A.R., Collier, L.S., Flores, R.A., Santos, V.M., Silva, L.L., Oliveira, V.A., Barbosa, J.M., 2015. Productive Yield of Cowpea and Maize in Single Crop and Mixtures in an Agroforestry System. American-Eurasian Journal of Agriculture \& Environmental Science 15(1), 85-92.

Singh, A.N., Singh, J.S., 1999. Biomass, net primary production and impact of bamboo plantation on soil redevelopment in a dry tropical region. Forest Ecology and Management 119, 195-207. 